\title{
ECO-FRIENDLY REUSE OF MARBLE WASTES IN LANDSCAPE AND ARCHITECTURE
}

\author{
KATIA TALENTO ${ }^{1}$, MIGUEL P. AMADO ${ }^{1} \&$ JOSÉ C. KULLBERG $^{2}$ \\ ${ }^{1}$ CERIS/Instituto Superior Técnico, University of Lisbon, Portugal \\ ${ }^{2}$ Earth Sciences Department and Geobiotec, Nova University of Lisbon, Portugal
}

\begin{abstract}
The Anticlinal of Estremoz, in Portugal, is one of world's main sites of marble extraction. Annually, millions-of-tons of marble are extracted from the multiple quarries present in the area, but only $9 \%$ of picked material is marketed because only this percentage is considered of "quality". Due to economic reasons, today, only a small number of quarries remains active and this has contributed to the degradation of the site. The remaining $91 \%$ of the unused material is shelved in stone accumulations, designated by "Escombreiras", creating a strong impact on the landscape that cannot be disposed due to cost. The present research is based on the paradigm shift of going beyond the appearance, considering the mounds of waste not as imperfections but as having a great eco-friendly potential for the requalification of the area. Their reuse will be the basis for the promotion of new buildings inside and above the mounds of waste, integrated with the surrounding landscape, ecology and geology using interdisciplinarity as the key driver for innovation. The advantages are: sustainability, because it uses the local waste materials that are reused in situ preserving the identity of the industrial place; there will also be energy savings, because the wastes don't need to be moved elsewhere; finally, the buildings will be naturally heated or cooled due to the large thickness of the marble walls and other inherent features. Therefore, these buildings can generate nearly zero emissions of $\mathrm{CO} 2$ and they will contribute to the reduction of pollution, helped by the presence of the existing vegetal cover, which fixes the pollutants in the air and produces oxygen. The abandoned area will be transformed into a liveable and sustainable touristic place, reusing, in a contemporary way, the concept of vernacular architecture, keeping the tradition, but also using the present technologies to achieve significant energy savings.

Keywords: quarry, waste, marble, reuse, recycle, Estremoz-Anticlinal, Portugal.
\end{abstract}

\section{INTRODUCTION}

The current contemporary epoch where we belong shows absolutely an ample interest in landscape. While in the past, it represented only a negligible component, nowadays it has become the emblem of the society that looking at the landscape as a popularized and democratized element [1]. The difference of the landscape concept between "yesterday" and "today" is evident, in fact, while over the past years it has always seen as a mere background of the artistic scenes [2], in the present days on the contrary, it has become a central element in many disciplines, such as the geography, philosophy, art, architecture, engineering and sociology [1]. Especially in the artistic field, for example in the Land Art movement, the landscape is considered with a renewed approach, where it represents the main subject that can be modified, permanently or not, with the introduction of giant installations [3]. In accordance to the explications above, we understand that the landscape, little by little, has changed and grown its importance and it has also influenced by man activity. The philosopher Malcolm Budd considered the real landscape as the nature doesn't altered by man [4]. Recognizing that we live in a contemporary era that it has become the symbol of a strong industrialization and of the insistent brand of man on the territory, is it possible to speak about the notion of "untouched nature"? This conception does not fit in our current age, where on the contrary, we have assisted, with a nostalgic feeling, to the loss of the landscape. Indeed, the original territorial structure has been permanently changed by the growing industrialization and its consequential and environmental problems [5]. 
Being the industrial activity that causes more metamorphosis and being the main matter of this research, the work pays attention to the analysis and the description of the extraction sites. They have modified, and still modify, the landscape in a more invasive way. The effects of the strong industrialization are much more visible in this case and the result of this situation is not only the inclusion of the industrial buildings on the territory, but the entire transfiguration of the morphology and physiognomy of the landscape along with its economy, social structure and environment quality [6], [7].

Most often, due to crisis of the building sector and due to economic and geological reasons, a considerable number of quarries is subjected to abandonment or closure. Vulnerable to a brutal materials removal, the quarries are forced to see their state completely changed, and there is no hope for them to return to the original condition. For these reasons, they are definitely considered as the symbol of the gap, turning them into brownfields [7].

The brownfields are places of degradation, previously exploited for industrial scopes, that they can be seen as a depreciation of the landscape and an ecological, aesthetic and social loss [8]. Many other terminologies can be utilized to define the residual and abandonment spots but, the most important are: "Friche" [9], "Terrain Vague" [10], "Wasteland" [11], "Drosscape" [12], "Derelict Land" [13], "Terra incognita" [14], "The third landscape" [15], "Zero panorama” [16], "Urban sinks” [17], "Dead zones” [18], "Il vuoto" [19], "In between spaces", "White areas", "Blank areas" and "SLOAPs" (Spaces Left Over After Planning) [20]. Despite the abundance of definitions, these discarded landscapes are gathered to a unique aspect, namely that of have been expelled from the cities for their incompatibility with the urban phenomena. This incompatibility is represented by the wastes from which the abandoned landscapes are characterized.

Nowadays, it is important considering these devastated territories as part of the current landscape because it means operating on the most delicate part of the city. In this context, the architect plays the role to integrate these wastes in the urban process and development [21] through recycling operations careful about the respect and the protection of the environment and the sustainability [22].

The word "recycle" means reusing the discarded material that has lost its meaning and its virtue. It is a procedure to reduce wastes, creating a new sense and another life in the "disoriented" landscape [23]. Working with these types of landscapes means to consider them as sites rich in history and, consequently, the rehabilitation project should regulates on this concept, not considering the landscape as a "tabua rasa" or a "blank page" where it is possible to draw every type of modern idea [5].

The secret of the rehabilitation is to project the landscape in the past and in the future to transmit tradition, culture and knowledge [24] and the challenge is how to see something common in a new fresh way and how to make old things new [25]. In this sense, it is preferable giving an innovative aspect to the abandonment factor and not to build, in an uncontrolled way, new landscapes without identity [26].

Based on this innovative point of view, the original conception of the landscape has been completely reviewed, including also the word "gap" in its repertoire. Consequently, methods able of communicating with the wastes are been elaborated to demonstrate the openness of the landscape for the dynamics of the time and to prove that the wastes are not always adverse elements to check out; in fact, they have a great potential of reuse and transformation of the aspect of the industrial landscapes [27], [28].

This paper represents an academic contribution, providing, through a brief explanation of the concept of the landscape (jointly with its change and its way of requalification and reuse), greater attention toward the abandoned and industrial territories, in particular toward the extraction sites. In the present times, there is an increasing social interest in environmental 
problems and it is important to investigate how to turn dismissed quarries into profitable and appreciable areas improving, at the same time, the quality and the beauty of landscapes and reinforcing the concept of the identity of a place in a changeable and wasted context. This is the main scope of the current research and, starting from these premises, another objective of the present article is to determine, through the analysis of several existing examples of quarry rehabilitations, some guidelines for future shaping of post-mining landscapes. In this manner, the formulation of clear criteria of valorisation of quarries and their surroundings, as well as the opportunity of their modelling, are possible.

Section 2 describes the quarry industry with its definitions, and it discusses the importance of the rehabilitation concept with the illustration of several real examples of quarry requalification. Section 3 shows the case study and the fundamentals of the current research. Finally, Section 4 draws the main conclusions.

\section{THE QUARRY INDUSTRY}

\subsection{Definitions and the importance of the rehabilitation concept}

As mentioned above, belonging to the scope of this research, the work will focus on analysing and describing the quarry, which is any site of open-air excavation of rocks and minerals [29]. Minerals are mainly relevant in every sector, from that of construction to manufacturing industries and they are the base for most productive activities. The possession of these minerals represents, since millennia, a strategic factor for the growth of the economy of a country and for the evolution of the industrial relations [30].

Similar to mining activity, the cultivation of a quarry can be classified in three different categories: open air (type of quarry used to extract deposits of mineral near the surface), underground (requires equipment and workers to operate under the surface of the earth) and pit (type of open pit typical for flat areas, where mining is carried out along graded surfaces that extend downwards to below the level of the countryside).

The extractive industry, normally, is connected to the geological conditions of the territory, where it is placed, and to the location of the mineral substances. This situation, since there is no economically viable alternative to produce these indispensable resources for our society, often entails the necessity to operate the mineral in non-optimal conditions (for example in difficult environmental situations or the proximity to the inhabited settlement of a city) [31]. Consequently, the cultivation project is conditioned by several aspects, such as the deposit location, the mineral value, the geographic area, the transport networks, the geo-mechanical characteristics of the soil and the social political system [32].

One of the most brutal consequences produced by the extraction activity is, undoubtedly, the destruction of the landscape in its geographical sense. This type of industry in fact, is an important form of degradation of the territory made by man, so far as to alter or even to break the fragile natural equilibrium achieved over thousands of years [33]. The presence of a quarry or of a system of quarries on the territory affects, considerably, the ecological, hydrological and pedological balance, provoking an irreversible mutation of the territorial context (such as the loss of the high-quality components of the landscape) [34]. Precisely from these premises derives the urgency of evaluating the alterations produced by the quarries, not only in the aesthetic field but also considering a large range of effects provoked in the entire pre-existing ecosystem.

The reasons behind the rehabilitation of the quarries are attributable to the safeguarding of the private and public security, to the rebalancing of the hydrological and morphological characteristics of the sites and to the production of income [34]. Several authors [35], [36], 
sustain there are three recovering typologies: the destination for productive, social purposes and the renaturalisation. Sometimes, the choice of the final destination is conditioned by some variables, such as the nature of the extracted material, the adopted extraction technique and the morphological, settlement and environmental conditions [32].

Specifically, the destination for productive scope (including agriculture and tourism), is preferable in an area rich in population density, residential and productive settlements, or it is excellent in correspondence of marginal places with specific vocational characteristics (for example the presence of attractions or favourable climate) [37]. The utilization for social purposes aims to allocate the contaminated sites to marginal, essential and low-cost uses. The quality and the good outcome of these projects depend on many factors, such as the quantity of financial resources, the type of service to offer, the level of specialization and the presence of connected infrastructures.

The renaturalisation programs aim to reproduce the environmental conditions prior to the industrial cultivation, through a series of different ecological, technological and financial operations. In abundant cases, we witness the attempts of artificial reconstitution of the landscape and, according to Trasi [35], it is evidently illogical thinking to get a place to the status quo, because quarries and mines have completely modelled the environment. They have transformed not only the physical geography but also the human geography and the abandonment of a territory, by those who have exploited it, highlights a distorted world in nature and economy.

As reported by Oneto [38], the realization of surroundings characterized by natural aspects and capacity of adaptation and self-substantiation, is more realistic. The recovery of a quarry should consent a harmonious reinsertion in the site, using materials and techniques with low environmental impact [37]. Traditionally, the objective of a quarry requalification has always been that to reconstitute natural landscapes in a way to eliminate the traces of the human activity, with the scope to reproduce an uncontaminated nature. Recently, in contrast to this first methodology, a current of thought has been developed, that aims to recover the discarded areas in relation to the anthropic space and not to the natural one. From this conception derives the definition of the quarries as "places to reinvent" and not as "voids to fill" [32]. Nowadays, the Land Art movement, with its aesthetic and ecological impacts, has given a significant input to this last method; thanks to this creative phenomenon and to "the faith in a poetic response", the re-project of a quarry is more connected to the territory [34]. Based on these affirmations, the restoration and the requalification of industrial areas could also represent an advantage for the entire community, for improving the quality of life in urban/suburban areas and for the biodiversity, by creating new habitats for the flora and fauna [39].

\subsection{Some existing examples of quarries reconversion}

After their exploitation, quarry areas can constitute an opportunity for territorial development, and they can be appreciated for several reuses. The idea to recycle and to give a new life to abandoned spaces is not new [39]. Back to the Renaissance in fact, a meaningful case is that of Boboli Gardens in Florence (Italy), a former sandstone quarry that provided material for the first paving of Florence streets [40]. There are many examples in the world of formed dismissed quarries that, once reclaimed or restored, they have acquired scenic, ecological, recreational, educational and scientific value, since they are usually located in areas of superlative natural beauty [39]. To better organize some of the selected requalification projects, they have been grouped by country, alphabetically ordered, as illustrated in Table 1. 
Table 1: Some of selected quarry rehabilitation projects.

\begin{tabular}{|c|c|}
\hline Country & Quarry Rehabilitation Project \\
\hline Croatia & $\begin{array}{l}\text { - Montraker. } \\
\text { International summer school of sculpture located in an active and Vrasar } \\
\text { stone quarry. Project and realization in } 1991 .\end{array}$ \\
\hline Denmark & $\begin{array}{l}\text { Hedeland. } \\
\text { - Regional park with natural areas, sports facilities, amphitheatre and other } \\
\text { equipment in a former gravel and clay quarries [41]. } \\
\text { - Rordal Lake Park. } \\
\text { Park for aquatic sports with open-air theatre in a gypsum quarry [31]. }\end{array}$ \\
\hline France & $\begin{array}{l}\text { - Bois-le-Roi } \\
\text { Public Park with bathing area in a sand quarry [35], [41]. } \\
\text { - Cergy Ponds } \\
\text { Park located in Cergy/Neuville with lakes for aquatic sports, swimming } \\
\text { pool, tennis and golf courts, equestrian trails and naturalistic areas in a sand } \\
\text { quarry [40]. } \\
\text { - Crazannes } \\
\text { Rest area La Pierre de Crazannes with open-air museum in a marble } \\
\text { quarry [35], [41]. } \\
\text { - Firminy } \\
\text { Stadium and Youth and Culture Home in a coal quarry designed by Le } \\
\text { Corbusier [35], [41]. } \\
\text { - Portel winery } \\
\text { Winery and quarry museum in a gypsum quarry [31]. } \\
\text { - Beinheim port } \\
\text { River port on the Rhine for barges, commercial boats in a sand and gravel } \\
\text { quarry of alluvial origin [31]. }\end{array}$ \\
\hline Germany & $\begin{array}{l}\text { - Westpark } \\
\text { Urban Park in Munich suburb with show rooms, exhibition spaces, } \\
\text { greenhouses and amphitheatre in gravel quarries [35], [41]. } \\
\text { - Emscherbruch } \\
\text { Landscaped park with recreational areas (skating rink, mountain bike) in } \\
\text { Ruhr basin in coal mines [40]. } \\
\text { - Rheinelbe } \\
\text { Naturalistic Park with garden school, seat of IBA Emscher Park, in a coal } \\
\text { mine [41]. } \\
\text { - Landschaftskunst Goitzsche } \\
\text { Recovery of lignite mines for touristic-bathing purposes, near Bitterfeld } \\
\text { and Pouch [42]. } \\
\text { - Karsdorf Vineyard } \\
\text { Vineyard and afforestation in Karsdorf in limestone quarries [40]. }\end{array}$ \\
\hline
\end{tabular}


Table 1: Continued.

\begin{tabular}{|c|c|}
\hline Country & Quarry Rehabilitation Project \\
\hline Holland & $\begin{array}{l}\text { - Broken Circle and Spiral Hill } \\
\text { Land art pieces in a sand quarry in Emmen [45]. } \\
\text { - Zanderij Quarry } \\
\text { Terraced Park with botanical collections in an aggregates quarry [46]. }\end{array}$ \\
\hline Italy & $\begin{array}{l}\text { - La Mortella Gardens } \\
\text { Gardens in a trachyte quarry in Ischia, spaces for artistic manifestations } \\
\text { and concerts and International Center for young composers [54]. } \\
\text { - Isola Giarola Quarry } \\
\text { Area for recreational, naturalistic and productive (fish farming) purposes in } \\
\text { a sand quarry near Piacenza [33]. } \\
\text { - Ca' Trebbia } \\
\text { Agricultural recovery in a gravel quarry near Piacenza [33]. } \\
\text { - Gym Free climbing } \\
\text { Rock Gym in a stone quarry in Rome [41]. } \\
\text { - Fornace Park } \\
\text { Agricultural and wildlife Park in Cambiano with spaces for scientific and } \\
\text { cultural activities, clay Eco museum in a clay quarry [55]. } \\
\text { - Quarries Hotel } \\
\text { Tourist settlement and anthropological ethno museum in white tuff quarries } \\
\text { in Favignana [40]. } \\
\text { - Private House } \\
\text { House in a tuff quarry in Favignana [40]. } \\
\text { - Luneo Quarry } \\
\text { Oasis WWF in a clay quarry with spontaneous renaturalisation [40]. } \\
\text { - Rubbio Quarry } \\
\text { Studio and artistic laboratory with open-air amphitheatre near Vicenza [56] } \\
\text { - Sardegna Geo-mining Park in Cagliari [57]. }\end{array}$ \\
\hline Portugal & $\begin{array}{l}\text {-Braga Stadium } \\
\text { Stadium in a stone quarry on the north side of the Monte Castro in Braga }\end{array}$ \\
\hline $\begin{array}{l}\text { United } \\
\text { Kingdom }\end{array}$ & $\begin{array}{l}\text { - Eden Project } \\
\text { Thematic Park in St. Austell, in a kaolin quarry, with greenhouse, } \\
\text { experimental gardens on the planet's biodiversity and open-air } \\
\text { amphitheatre [47], [48]. } \\
\text { - Druridge Bay } \\
\text { Territorial Park with artificial lakes, seaside resort and naturalistic oasis in } \\
\text { a coal quarry in Cresswell [49]. } \\
\text { - Blue Water } \\
\text { Shopping Center in a limestone quarry in Greenhithe [40]. } \\
\text { - Blue Circle } \\
\text { Wooded areas and golf course in clay quarries [50]. }\end{array}$ \\
\hline
\end{tabular}


Table 1: Continued.

\begin{tabular}{|l|l|}
\hline Country & Quarry Rehabilitation Project \\
\hline Romania & \begin{tabular}{l} 
- Field of sculptures \\
Open-air ethnographic museum in a limestone quarry in Màgura [51]. \\
\hline - Fossar de la Pedrera \\
Semorial Park in a stone quarry in Barcelona [41]. \\
- Hill-quarry in the Denia port \\
Commercial and touristic centre in a limestone quarry, located in a port \\
area, with hotel, auditorium, parking and terraced gardens [52]. \\
- Tindaya Mountain \\
Exhibition space and land art intervention in a marble quarry of Tindaya \\
Mountain [41].
\end{tabular} \\
\hline Sweden & $\begin{array}{l}\text { - Memory Forest } \\
\text { Cemetery Park in Enskede in a gravel quarry [53]. }\end{array}$ \\
\hline Switzerland & $\begin{array}{l}\text { - Musital Quarry } \\
\text { Naturalistic recovering of a limestone quarry [41] }\end{array}$ \\
\hline
\end{tabular}

According to the concept of waste reuse from quarries, there are many publications concerned with this problem, which propose ideas for the recycle of the residues. Their applications are so many, for example the wastes are used in glass, chemical, pharmaceutical, environmental, agricultural, plastic, steel, metal, textile, and construction industry to public works. The few applications that can lead to a large consumption of this waste material are those that are oriented to civil construction industries, for the production of lime, cement, and concrete for calcining acid soils in the agriculture sector, for the composition of bituminous mixtures useful to road constructions and aerodromes in the civil engineering sector. In summary all these applications, mentioned above, treat the marble-wastes in the way that they are partially removed from the original place and used elsewhere [7].

\section{CASE STUDY - THE QUARRIES OF THE ESTREMOZ-ANTICLINAL IN PORTUGAL}

\subsection{Site features}

The biggest marble explorations of Portugal are placed in the municipalities of Estremoz, Borba and Vila Viçosa. These municipalities belong to the Alentejo region and to the Estremoz-Anticlinal, a geological formation with an area of $280 \mathrm{~km}^{2}$, located $50 \mathrm{~km}$ from the city of Évora, in the central interior of the country. Especially in Vila Viçosa, resides the greatest concentration of the quarries, marble, and wastes.

Although the Alentejo region has always had a hot climate in the summer and a control of the water, the Estremoz-Anticlinal, on the contrary, has always been characterized by a great abundance of water, since its location in a large aquifer named "Estremoz-Cano System". One of the positive consequences of this abundance is the natural formation of gardens which contrasting with their context, since their much greener aspect [58]. 
In opposition to this natural aspect of the Estremoz-Anticlinal, there is also an artificial side, made by man, characterized by the presence of a huge quantity of marble that represents a symbol of a strong industrialization of the region. Despite the initial improvements of the economy of the country, the constant opening of many quarries destroyed the original landscape, rich in olive groves, vineyards and cork trees. The territory in fact, after exploitation, has turned completely degraded due to the presence of several open pits and a considerable number of wastes.

Due to quality "defects" of the material, of the all extracted marble, only a small percentage (about 9\%) is commercialized and the remaining part (about 91\%) is accumulated in huge piles of residual stone, named in Portuguese "Escombreiras" (Fig. 1). The reasons are related, for instance, to:

- The intense fracturing of the rocks, which causes the presence of small/medium blocks, do not appropriate to the sale.

- The existence of spots which drastically reduces the commercial value of the stone, making it unusable.

- The karstification of the marble which affects the quality and the management of the exploration, increasing at the same time, the quantity of waste material.
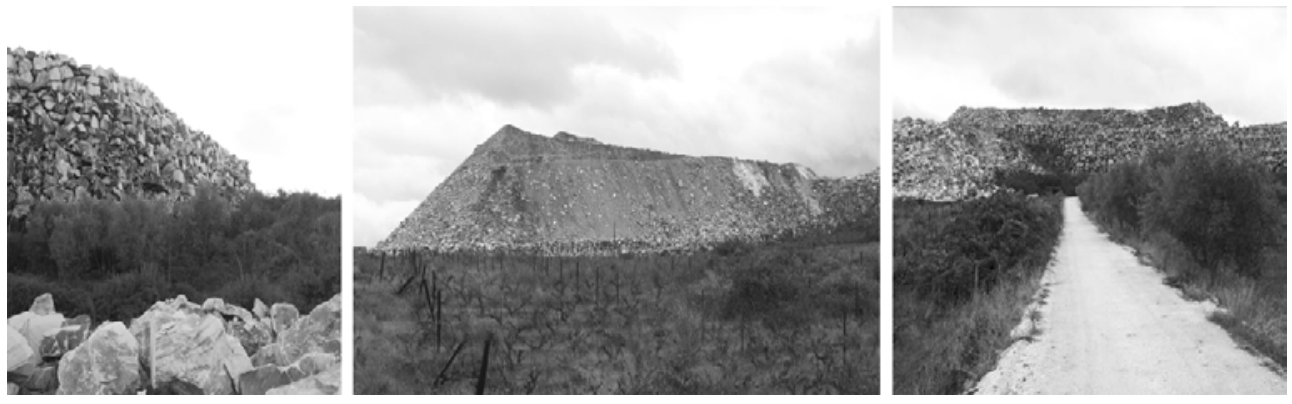

Figure 1: "Escombreiras", mounds of marble wastes.

For all these reasons, the marble is used only in a small amounts in several industries and for building use, road paving material, production of artificial aggregates and soil $\mathrm{pH}$ corrections [59]. The remaining part of it still persists on the territory to "deface" the landscape, since the big mounds of wastes cannot be disposed elsewhere due to economic limits. In fact, much costs can be added either in relation to the transport of this residual material to landfills, nearby or far away, or in relation to the work of the individual manufacturing operators.

The enormous quantity of wastes, at the same time, also causes environmental problems, such as the presence of stone dust which floats through the air and on the vegetation. The dust is also a reason for all the respiratory and ocular problems and skin irritations for men which working in the quarries [58].

\subsection{Current research}

The redevelopment of the industrial area of the Estremoz-Anticlinal has always been widely debated, according to two distinct approaches and concerning, on one hand, the requalification of the quarries, and, on the other hand, the reuse of marble wastes with their 
transformation. The first one consists in working in the place, and the second one consists in working off-site, exporting the material which the Escombreiras are composed.

The proposal described in this paper, in both cases, chooses to act exclusively in situ, not exporting any type of material. These mounds of waste in fact, could be seen in a different way, not as defects to be suppressed, but as original elements to promote the redevelopment of the area and the tourism of the region. Based on this observation, it is possible to affirm that the requalification of an industrial place, such as this of the Estremoz-Anticlinal, should consider the traces present on the territory for the design of new solutions to regenerate the landscape, giving a new meaning to what is common. In this sense, also the historical memory and the identity of the place are preserved. The Escombreiras can become iconic factors of the territory of the stone to give a mutable image of the landscape, coherent with its surrounding.

The ongoing research, in an embryonic state, proposes, through the conceptions discussed up to now, to redevelop the industrial landscape with the creation of buildings inside the Escombreiras, an innovative solution to incentive the tourism and the economic revival of the country. This proposal will connected with the surrounding and with the inactive quarries, after their requalification and securing. The operations of quarries redevelop, taking advantage of the natural features, spontaneously formed in the site (such as lakes, vegetation cover and the presence of new animal and vegetal species), will focus the attention mainly on the creation of green areas. This objective is useful to promote the biodiversity and the ecology and to generate touristic geo-spaces and areas of leisure, entertainment, recreation, sports and fun. These places will supply the new buildings, constituted inside the Escombreiras, and they will contribute to the formation of a big touristic system.

Regarding the conception of the buildings, the ongoing research started from one central idea that, successively, it has spread to two others. They are natural consequences of the first idea and they represent, considering the difficulty of the present case, efforts to simplify the creative process. All of these have in common the notion to convert the mounds of wastes in real buildings having self-utility and self-identity, and the concept to preserve the exactly position and shape of the marble piles.

The first approach consists in to aggregate the marble wastes, through an appropriate material (such as concrete or cement), creating blocks, with controlled dimensions, which can be disposed according to a given form. The same blocks will be anchored to each other and, at the same time, to several steel grids, which provide a greater resistance to the accumulation of the residues. After this operation, the construction process continues with the excavation (starting from the bottom) of the chosen central residual part for the formation of "empties", in which to create the interior system of the building [60] (Fig. 2(a)). The second example concerns the construction of touristic buildings, situated on the top or attached to the mounds of wastes.

This method considers the Escombreira as an artificial reinforced mountain, and as a "mini touristic village", having also the usual services (Fig. 2(b)). The building walls can be constructed reusing the wastes from the other Escombreiras, present in the place. Finally, the last approach looks at the solution with a simpler way and, for the creation of empties inside the central part of the Escombreira, it actuates a "cut of the mountain", instead of excavating the material as it happens in the first idea. Specifically, this "cut" will be possible with the insertion (from the top to the bottom) of two walls, inside the Escombreira, to support the entire system. Successively, the residual part between these two walls will be removed and the void that will be created by this operation, will represent the interior part of the building (Fig. 2(c)). 


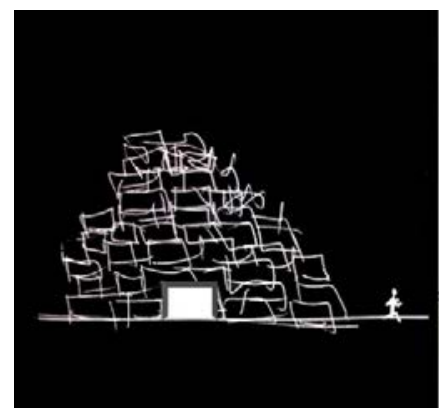

(a)

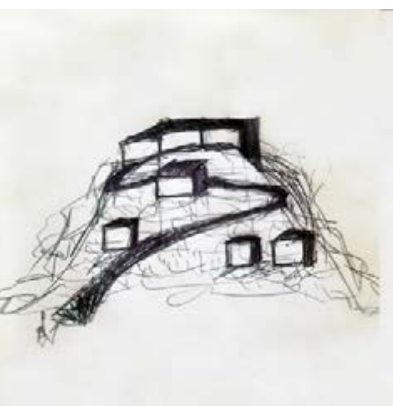

(b)

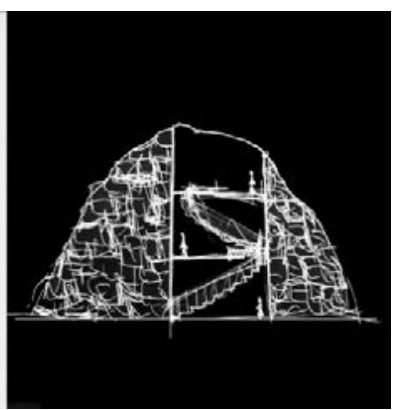

(c)

Figure 2: (a) Building inside the Escombreira, excavating the material; (b) Building on the Escombreira; (c) Building inside the Escombreira, "cutting" the mound of wastes.

The advantages of these solutions are: sustainability because it uses the local waste materials that are reused in situ, preserving the identity of the industrial place; there will be energy savings because the wastes don't need to be moved elsewhere; finally, the buildings will be naturally heated or cooled due to the large thickness of the marble walls and other inherent features. Therefore, these buildings can be a nearly zero emissions of $\mathrm{CO} 2$ and they will contribute for the reduction of pollution helped by the presence of the existing vegetal cover, which fix the pollutants in the air and produces oxygen. The abandoned area, in this way, will be transformed into a liveable and sustainable touristic place reusing, in a contemporary way, the concept of vernacular architecture, keeping the tradition, but also using the present technologies to achieve significant energy savings.

\section{CONCLUSIONS}

The paper, after having briefly illustrated the change of the landscape caused by man activity, has paid attention to the extraction sites. This industrial industry represents the principal theme of the current research and it has always seen as an activity which causes more metamorphosis of the landscape. The main consequence is the transfiguration of the entire morphology and physiognomy of the landscape along with its economy, social structure and environment quality. The article, after giving some real examples of quarries requalification in different parts of the world, has described a case study in Portugal (Estremoz-Anticlinal), where resides the highest concentration of marble quarries and wastes, accumulated in huge piles of material (named in Portuguese, Escombreiras). The intention of the research is to give importance to the concept of the waste reuse and to preserve the identity of the place. New solutions to rehabilitate the quarries and to use the mounds of wastes, rather than to break down them, have been described. The article has shown, in fact, the interest in transforming an industrial site into an active touristic place, having also aesthetic quality, with the introduction of touristic buildings inside the Escombreiras and the integration of them in the surrounding.

\section{ACKNOWLEDGEMENTS}

The first author would like express gratitude to the Fundação para a Ciência e Tecnologia. The authors also would like to thank Professor Paulo Caetano from the Department of Earth Sciences, Faculty of Sciences and Technology, NOVA University of Lisbon and GeoBioTec for providing the photos in Fig. 1. 


\section{REFERENCES}

[1] Jakob, M., Il Paesaggio, Il mulino: Bologna, 2009.

[2] Ribeiro, O. \& Lautensach, H., Geografia de Portugal, vol. 1., Edições João Sá da Costa, 2009.

[3] Tufnell, B., Land Art, Tate: University of California, 2006.

[4] Budd, M., The Aesthetic Appreciation of Nature: Essays on the Aesthetics of Nature, Clarendon Press: Oxford, 2002.

[5] Veríssimo Serrão, A., Filosofia da Paisagem, Uma Antologia, 2nd ed., Centro de Filosofia Universidade de Lisboa: Lisbon, 2011.

[6] Cipriani, L., Vita e Morte del Paesaggio Industriale, Università degli Studi di Trento: Trento, 2012.

[7] Talento, K., Amado, M. \& Kullberg, J.C., Landscape - A review with a European perspective. Land, 8(85), 2019.

[8] Dumesnil, F. \& Ouellet, C., La réhabilitation des friches industrielles: Un pas vers la ville viable? Vertigo la Revue Électronique en Sciences de l'Environnement, 3(2), 2002.

[9] Chaline, C., La Régénération Urbaine, Paris, France: Presses Universitaires de France, 1999.

[10] Barron, P., Terrain Vague: Interstices at the Edge of the Pale, Routledge: London, 2013.

[11] Nabarro, R. \& Richards, D., Wasteland: A Thames Television Report, Thames: London, 1980.

[12] Berger, A., Drosscape. Wasting Land in Urban America, Princeton Architectural Press: New York, 2007.

[13] Kivell, P. \& Hatfield, S., Derelict land - Some positive perspectives. Environment, Planning and Land Use, Ashgate: Aldershot, pp. 118-129, 1998.

[14] Bowman, A. \& Pagano, M., Terra incognita: Vacant Land and Urban Strategies, Georgetown University Press: Washington, DC, 2004.

[15] Clement, G., Le Manifeste du Tiers-Paysage, Editions Sujet/Objet: Paris, 2003.

[16] Smithson, R., Sites and settings. Robert Smithson: The Collected Writings, University of California Press: Berkeley, 1996.

[17] Lynch, K., Wasting Away, Sierra Club Books: San Francisco, 1990.

[18] Doron, G., The dead zone and the architecture of transgression. City: Analysis of Urban Trends. Culture, Theory, Policy, Action, 4(2), pp. 247-263, 2000.

[19] Secchi, B., II Vuoto. Un Progetto per L'Urbanistica, Einaudi: Turin, 1989.

[20] Jonas, M. \& Rahamann, H., Tokyo Void: Possibilities in Absence, Jovis Edition: Berlin, 2015.

[21] Di Marco, C., La Riconversione dei Paesaggi di Scarto: Saint-Étienne, da Cittá Nera a Cittá del Design, Dipartimento di Architettura, Universitá degli studi Federico II: Naples, 2016.

[22] Marini, S. \& Santangelo, V., Re-Cycle Italy. Nuovi Cicli di Vita per Architetture e Infrastrutture della Città e del Paesaggio, Aracne: Rome, 2013.

[23] Tarpino, A., Spaesati. Luoghi dell'Italia in Abbandono tra Memoria e Futuro, Passaggi Einaudi: Turin, 2012.

[24] Bonesio, L., Oltre il Paesaggio. I Luoghi tra Estetica e Geofilosofia, Arianna Editrice: Bologna, 2009.

[25] Olin, L., Form, meaning, and expression in landscape architecture. Landscape Journal, 2, pp. 149-168, 1988.

[26] Cervellati, P.L., L’Arte di Curare la Città, Il mulino: Bologna, 2000. 
[27] Marini, S., Spazi Bianchi. Progettare lo scarto. L'Architettura e le Sue Declinazioni, Ipertesto: Verona, 2008.

[28] Marini, S., Nuove Terre. Architetture e Paesaggi dello Scarto, Quodlibet: Macerata, 2010.

[29] Fornaro, M., Lovera, E. \& Sacerdote, I., La coltivazione delle cave e il recupero ambientale. Estrazione di Materiali per usi Industriali e Pietre Ornamentali, vol. 1, Politeko: Turin, 2002.

[30] Conti, S., La produzione mineraria ed energetica. Geografia dell'Economia Mondiale, Utet: Torino, pp. 123-156, 2006.

[31] Brodkom, F., Codice di Buona Pratica Ambientale nell'Industria Estrattiva Europea, PEI srl: Parma, 2001.

[32] Gisotti, G., Le Cave. Recupero e Pianificazione Ambientale, Flaccovio Dario: Palermo, 2008.

[33] Muzzi, E. \& Rossi, G., Il Recupero e la Riqualificazione Ambientale delle Cave in Emilia Romagna, Arketipa: Bologna, 2003.

[34] Labianca, M., La riqualificazione dei siti estrattivi: un'opportunità per il territorio. La situazione della Puglia. Rivista Geografica Italiana, 120(1), pp. 55-70, 2013.

[35] Trasi, N., Paesaggi Rifiutati. Paesaggi Riciclati. Prospettive e Approcci Contemporanei. Le Aree Estrattive Dismesse nel Paesaggio: Fenomenologia di un Problema Progettuale, Dedalo: Rome, 2001.

[36] Ballestrazzi, G., Guida all'industria Estrattiva e al Riciclaggio, PEI srl: Parma, 2006.

[37] Mazzanti, R., Il Recupero di Aree Degradate dall'Industria Estrattiva, Felici: Pisa, 1993.

[38] Oneto, G., I molti aspetti del recupero ambientale. Discariche, Cave, Miniere ed Aree Difficili o Inquinate, Pirola: Milan, pp. 1-56, 1989.

[39] Coratza, P, Vandelli, V. \& Soldati, M., Environmental rehabilitation linking natural and industrial heritage: A Master Plan for dismissed quarry areas in the Emilia Apennines (Italy). Environmental Earth Sciences, 77(455), 2018.

[40] Fondazione Benetton Studi e Ricerche (FBSR), Cave. Per un Atlante Storico Geografico delle Cave del Veneto. Reinvenzioni e Riusi, Fondazione Benetton: Treviso, 2006.

[41] Caramagno, V., Nuovi paesaggi per le aree estrattive dismesse, $\mathrm{PhD}$ thesis, Università Mediterranea di Reggio Calabria: Reggio Calabria, 2004.

[42] Schierz, H., Aufbruch zu neuen Ufern, Verlag Stekovics: Halle an der Saale, 2001.

[43] Pavan, V., Nuovi Paesaggi di Pietra, Veronafiere: Verona, 2000.

[44] Golanda, N. \& Kouzoupi, A., The old quarries of Dionyssos, Attica, Greece. Topos, 36, pp. 24-28, 2001.

[45] Arbogast, B.F., Knepper, D.H. \& Langer, W.H., The Human Factor in Mining Reclamation, U.S. Geological Survey Circular 1191: Denver, 2000.

[46] Aguado, M. \& Carrascal, X., Interventi sul territorio: un repertorio di esempi. Luoghi Pubblici nel Territorio. Una Proposta per le Cave del Casertano, Gianni Editore: Naples, pp. 59-85, 2001.

[47] Muzzillo, F., Eden Project in Cornovaglia. Architettura del Paesaggio, 9, pp. 26-29, 2002.

[48] Holden, R., Progettare l'Ambiente, Logos: Modena, 2003.

[49] Zoppi, M., Vuoti Urbani, Progettare con il Verde, Alinea: Florence, 1989.

[50] Spens, M., The Complete Landscape Designs and Gardens of Geoffrey Jellicoe, Thames \& Hudson: London, 1994. 
[51] Bernardi, U., Un museo locale per tutte quelle vite. Castellavazzo: Un Paese di Pietra, la Pietra di un Paese, Neri Pozza Editore: Vicenza, pp. 243-246, 1997.

[52] ERCO, Biennale di Architettura, Venice, 2004.

[53] Felicori, M. \& Zanotti, A., Cimiteri d'Europa. Un Patrimonio da Conoscere e Restaurare, Touring Club Italiano: Bologna, 2004.

[54] Boyden, M., Russel Page, Ritratti di Giardini Italiani. Catalogo della Mostra, Mondadori Electa: Milan, 1998.

[55] Associazione Nazionale Industriali dei Laterizi (ANDIL), Laterizio e Natura. La Riqualificazione Ambientale delle Cave di Argilla, Edizioni Laterservice: Rome, 2005.

[56] Rubbio, Estate alle Cave, vol. 5., Bassano del Grappa, Italy, 2005.

[57] Forsans, M.P., Dentro la miniera, a strapiombo sul mare. Il giornale dell'Architettura, 31, pp. 21, 2005.

[58] Baganha, P., Notes towards a project for the quarries landscape of Estremoz Anticline. Joelho. Revista de Cultura Arquitectónica, 6, 2015.

[59] Ulubeyli, G.C. \& Artir, R., Properties of hardened concrete produced by waste marble. Procedia Social and Behavioral Sciences, 195, pp. 2181-2190, 2015.

[60] Talento, K, Amado, M. \& Kullberg, J.C., The metamorphosis of the landscape: The adaptive reuse of marble waste. Proceedings of the 5th International Conference on Architecture and Built Environment with AWARDS, Venice, 2018. 